\title{
Pedagogical Issues Concerning Academic Advising
}

Tahmoures Afshar, (E-mail: tahmoures.afshar@woodbury.edu), Woodbury University Leo O’Hara, (E-mail: leo.ohara@woodbury.edu), Woodbury University

\begin{abstract}
This study examined whether, and to what extent, students' personal and cultural variables have an impact on the advising process. 225 students in an urban, private university were asked to complete twenty-nine structured questions in the Fall 2005. Each question asked the student to rank on a scale of one to five the importance of a characteristic/responsibility of an academic advisor. These twenty-nine characteristics/responsibilities were those most often cited in the literature as critical for an effective academic advisor. In addition, the students were asked to provide some cultural, personal, and academic information on themselves including class status, GPA, age, gender, school, and ethnicity. We used the chi-square testing technique. This method of testing the hypothesis allowed us not only to identify which of the advisor's characteristics and/or responsibilities were significant but also to identify which personal and cultural trait of the student a particular characteristic was most consistent with. We found that students with different variables had quite different perceptions of the advising process. Students' perceptions varied by age, class status, GPA, gender, school, and ethnicity. While there has been an increasing number of studies devoted to examining student satisfaction with academic advising, few of these studies have considered the student's cultural, personal, and academic background as determinant factors in a successful academic advising process.
\end{abstract}

\section{INTRODUCTION}

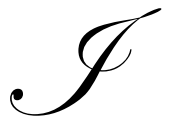

$\mathrm{t}$ is accepted by a good number of researchers that there is a positive relationship between college student retention and effective advising. Moreover, it is increasingly recognized that retention, and indirectly advising, has a major impact on a school's bottom line. Despite the growing recognition of the monetary importance of academic advising, it has not been one of the top priorities of colleges and universities. Even those academic institutions that have started to train their faculty in advising, their training programs focus on general skills and knowledge that are expected of all advisors. This kind of training program may have been sufficient at one time when college students were nearly homogeneous; but today most of higher educational institutions are faced with a diverse student body regarding ethnicity, age, gender, and family background. The same skill sets that were once sufficient are not beneficial to today's more diverse student body.

This paper provides direction and guidelines to those faculty advisors who advise diverse students in their institutions and who are attempting to improve their own advising skills. Obviously, good advising benefits both students and institutions. Our objective in this paper is neither to provide a training program for faculty nor to claim that our suggested concerns and views are equally applicable to all institutions. Rather we would like to offer a different perspective of academic advising. This perspective, like any new teaching method, will hopefully increase the advisor's effectiveness. Let us not forget that advising is also teaching and students expect the same high quality in both teaching and advising.

\section{REVIEW OF LITERATURE}

Numerous studies (Backhus 1989 and King 1993 among others) have explored the importance of effective academic advising on student retention rates. Burnett et al (2003) stated that the quality of an institution's student 
supporting system could make the difference between students who are enjoying a satisfying experience and those who are struggling with frustration and confusion. Studies by Astin (1993) and Light (2001) suggested that there was a positive correlation between student retention and satisfaction with advisor-student interaction. The advisor is a facilitator who brings about interactions between the student and institution, which ultimately may lead to student retention. Levitz et al (1999) stated that institutions experienced lower dropout rates when they had strong advising systems. Light suggested that "good advising may be the single most underestimated characteristic of a successful college experience" (p.81). Creamer (2000) stated the advising is a "form of teaching that is both complex and puzzling, and it's effectiveness depends on the sound use of multiple theories about students and the educational institutions in which they study" (p.18).

The literature has defined the student-advisor relationship as either perspective or developmental in approach. Under the perspective approach, the advisor assists the student with the registration process, major/minor decision-making process, and course selection. Under the developmental approach, however, the advisor works with the student to formulate an educational plan consistent with the student's life goals and objectives (Fielstein, 1989).

A study by Crockett (1978) indicated four major services that students expected from their advisors. These were a) accessibility, b) specific and accurate information, c) advice and counsel, and d) personal and caring relationship. A similar study by Kelly et al (1991) revealed empirically that students evaluate their advisors based on four criteria: a) socio-emotional, b) meeting dynamics, c) knowledge, and d) problems.

Lowe et al (2000) examined the academic advising process in a professional school. In their study students were asked to rate the importance of each advisor's responsibilities. Overall, twelve responsibilities were considered in their study. Similarly, a study by Afshar et al (2005) examined student satisfaction in an academic advising process using two advisory components. The first component was about student's needs and concerns such as: a) social and personal needs, b) information related concerns, and c) life goals and objective concerns. The second advisory component related to the advisor's characteristics and behavior in response to student's needs and concerns: a) interpersonal skills, b) information related skills, and c) attitudinal skills.

\section{PURPOSE OF OUR STUDY:}

While there has been an increasing number of studies devoted to examining student satisfaction with academic advising, few of these studies have considered the student's cultural, personal, and academic background as determinant factors in a successful academic advising process. For example, many adult students have special learning needs and personal preferences that require a special education and advising support services. Obviously, the advising interests of a freshman could be quite different than that of a senior student. Students in various Schools such as Business and Architecture would have different career goals and objectives as compared with students in Arts and Science. Students with lower GPA may require different advising handling than those with a higher score. Student gender differences, ethnicity, age, transfer status, full-time versus part time, longevity with current advisor, all these variables may call for new considerations in an effective academic advising process. Our present study attempts to close this gap in the literature by incorporating these issues into the study of the advising process.

Our goal in this study is to thoroughly test whether, and to what extent, these student variables have an impact on the advising process. The results of this study could then be incorporated into building a more effective advisory training program. Such a program would contribute to student retention and, thereby, have a direct impact on the University's bottom line.

\section{DATA}

For the purpose of this study, 225 students in an urban, private university, were asked to complete a structured questionnaire consisting of twenty-nine questions in Fall 2005, Table 1. Each question asked the student to rank on a scale of one to five the importance of a characteristic and/or responsibility of an academic advisor. These twenty-nine characteristics/responsibilities were those most often cited in the literature as critical for an effective 
academic advisor. In addition, the student was asked to provide some cultural, personal, and academic information on themselves including class status, GPA, age, gender, school, and ethnicity.

Demographic characteristics of students included in this study are described in Table 2.

\section{METHODOLOGY}

In an effort to increase our understanding of the pedagogical effectiveness of academic advising we employed the chi-square testing technique. This method of testing the hypothesis allows us not only to identify which one of the advisor's characteristics/responsibilities are significant but also to identifying which personal and cultural trait of the student this characteristic is most consistent with. In this study, we employed two sets of hypotheses testing at a 5\% significance level. The general form of the first set of hypothesis testing is as follows:

H0: In general population, there is no relationship between advisor's characteristics and student's attributes such as gender, age, etc.

H1: There is a consistent, predictable relationship between those two parameters (Gravetter, et al, 2004,p.596)

In this version of the hypothesis, we explored which one of the twenty-nine questions are favored by students considering all five given alternatives: very important, important, somewhat important, non- important, and do not know. By rejecting the null hypothesis, we concluded that there was a significant relationship between an advisor's characteristics and a student's attributes. Once a given characteristic/responsibility was identified as an appropriate tool in evaluating the advisor's effectiveness, then, the second version of the chi-square test was performed. This version of the chi-square involved testing the null hypothesis that all of the multinomial probabilities are equal. The form of this testing is:

H0: In the general population, the probability that a student's response to each selected question given any of five alternatives (very important, important, etc). is equal which would say that there is no significant difference, for instance, between male and female student's response in each question and in each alternative. If the null hypothesis was rejected in favor of:

H1: At least one response is preferred to another one. We would conclude that preferences for male and female students were not equal and either male or female students preferred the question more favorably.

Although these two versions of the chi-square tests are equivalent, we employed them separately to more clearly describe the outcome of our research. The second version of the test has enabled us to do some correlation between student's attitudes and perception and student's background rather than assuming that all students are alike.

\section{EMPIRICAL RESULTS}

We applied the first set of hypothesis testing to explore whether or not there is a significant relationship between each and every one of the twenty-nine questions and a student's gender, class status, ethnicity, GPA, age, and school. The results showed there is a consistent relationship between each question and a student's personal and cultural background. Our results, also, confirmed those of previous studies, which found that these twenty-nine characteristics and/or responsibilities were those that students perceived as the most significant for a successful academic advisor. Since in this step, we found a significant relationship, we then continued to report the results of the second set of hypothesis testing.

The second version of hypothesis testing attempted to explore whether or not there was a positive relationship between a student's response and the student's personal and cultural traits. The results were as follows: 


\section{Student's Gender Effect}

As evidenced from Table 2, there were 140 female participants as compared to 82 male students. We found a significant numerical difference in the responses of the two genders (female vs. male). For example, $92.7 \%$ of female students listed question \#19(knows requirement for graduation) as very important (their number one priority) compared to only $80 \%$ of the male students who designated this characteristic as very important (their second priority). This question can be viewed to address a student's "information related concerns" (Afshar, 2005). Another interesting difference was that $81 \%$ of the female students thought question \#12 (discusses course selection and helps me to select appropriate courses with my abilities) was 'very important', while for male students this activity was not even ranked in the top 10. Question 12 pertains to a student's information related/life goal needs. Likewise, question \#11(Seems to enjoy advising) was preferred by $54.7 \%$ of the male students whereas it was ranked as below average importance by female students. This question addresses a student's social and personal needs.

These few instances suggested that gender differences were evident in the students' responses. In order to demonstrate statistically whether our initial impressions were correct we applied the second version of the chi-square hypothesis testing. In this analysis, we examined whether there was a significant statistical difference between female and male students across the board. That is, we wanted to know whether in each and every question and every alternative (very important, important etc.) male and female responses were different.

For example, in the "very important" alternative female responses in all but two questions were significantly different from that of males using the 5\% significance level. Those two exceptional questions in which gender differences were not evident, were question \#9(addresses me informally by calling me by my first name) and \#29(makes most of my course selection decisions). In this instance, the null hypothesis was rejected overwhelmingly in favor of the alternative hypothesis. By rejecting the null hypothesis we concluded that preferences of female and male students are not equally probable and that gender differences indeed did exist.

However, in the "important" choice the result of testing the second version of chi-square was mixed. There was no significant difference between female and male responses in almost all questions except five. These five questions were \#18 (helps me to decide on a major/minor), \#20 (understands my point of view), \#22 (encourages me to make my own decisions), \#26 (is familiar with my academic background), and \#27 (understands my needs).

In other remaining choices, (somewhat important, not important, and don't know) no major gender difference was found.

\section{Student's Class Status Effect}

As shown in Table 2, there were 35 freshman, 47 sophomore, 75 junior, and 59 senior students in this study. In each class, female students outnumbered male students. Before reporting the results of the statistical analysis, we observed a few major differences in students' responses based on their class status. Table 4 lists the top ten choices by students based on class. Even a cursory review reveals that freshmen responses were quite different than those of the upper classmen. $71.4 \%$ of freshmen, for example, rated question \#3(is friendly) as very important while this question does not appear among the top ten choices of the other classes. Similarly, question \#1 (keeps personal information confidential), \# 8(is available during posted office hours), and \# 25(is a helpful, effective advisor whom I would recommend) were all selected by a large percentage of the other classes but do not appear among the freshmen's top choices. Perhaps, the latter did not have enough experience with academic advising thus, they did not have the vision and wisdom of older students.

To explore statistically, whether or not there were differences based on class status in student responses to all questions, we compared the following four pairs: 1) Freshman with sophomore, 2) Junior with Senior, 3) freshman with Senior, and 4) sophomore with Junior. We used only the "very important" alternative because it attracted the highest frequency of student responses. Table 5, summarizes the results of the second application of the chi-square test. 
We failed to find any significant differences between Junior and senior students in all twenty-nine questions. In twelve questions out of twenty-nine, the responses of freshman and seniors were quite different. Freshman and sophomore students differed on eight questions, and sophomores and juniors had different responses only in three questions. This analysis indicates that those questions that are very important for seniors were not equally important to freshmen. Similarly, those issues considered important for sophomores were not necessarily considered important for freshman. A closer analysis of table 5 reveals a very interesting phenomenon. In 18 questions, the response behavior of the Freshman/Sophomore pair and the Freshman/Senior pair were identical. In five of these questions, for example,: \#1, \#2, \#4, \#8, and \# 29, Freshmen responses were significantly different from both sophomores and seniors. These questions address a student's social and personal needs and the interpersonal skills of the advisor (Afshar, et al, 2005). The remaining 13 questions: \#3, \#6,\#,10,\#11, \#16,\#17,\#19,\#21-24, and \#25-28, were equally preferred at the $5 \%$ level of significance. Again, questions \#3, \#6, \#10, \#11 address the student's social and personal needs and the rest address the student's information related and life goal and objective needs (Same source). Our findings suggest that class status plays a role in a student's perception of what is important in the advising process. This is especially true of freshmen.

\section{Student's Ethnicity Effect}

As was shown in Table 2, there were 32 Armenian, 65 Hispanic, 25 Asians, 33 Whites, 10 African American and 26 others in our study. These categories were mutually exclusive and students nominated themselves for these ethnic groups. Again, female students dominated in these categories. The only exception is among African Americans where males out numbered females. These ethnic groups reflect the diversity in American colleges and universities today. Table six lists the top ten choices and their percentages of each ethnic group. For example, Armenian students' top ten choices were consistent with those of White American students. The responses of other ethnic groups, while similar were not as strongly related. Armenian and White American students' first priority was the trustworthiness of the advisor. This was the second choice of Asian and African American students. Armenian, Hispanic, and Asian students all indicated an advisor's experience as very important as opposed to White American and African American students. On the other hand, both Asian and African American students rated question \# 13(understands general studies and major requirements) as their first priority. So too, White American students did not list question \#12 (discusses course selection and helps me to select appropriate courses with my abilities), and question \$26 (is familiar with my academic background) among their top ten whereas all the other ethnic groups did. From this review of the top ten choices of each ethnic group, we concluded that ethnicity does matter in terms of a student's perception of his/her advisor.

However in order to confirm the significance of ethnicity we employed the second version of the chi-square hypothesis test. Once more we limited our analysis to the 'very important' alternative only and we considered nine pairs of observation: Armenian/Hispanic, Hispanic/Asian, Asian/Whites, Whites/African American, African American/Armenian, African American/Hispanic, African American/Asian, Hispanic/White, and Armenian/White. As expected, there was a significance difference in the responses of each member of the pair to virtually all twentynine questions. The responses of Armenian students, for example, were significantly different from those of Hispanic students ( $1^{\text {st }}$ pair), just as the responses of Hispanics significantly diverged from those of Asians ( $2^{\text {nd }}$ pair). The only exceptions were the Armenian/White pair and the Hispanic/White pair. In these two cases there was no significant difference in the probability of responses of one group over the other. On the other hand there was a significant difference in the responses of each member of the other pairs, especially five pairs (Armenian/Hispanic, Hispanic/Asian, African American/Hispanic, and Hispanic/white. Based on these results we conclude that ethnicity matters in a student's perception of the advising process.

\section{Student's GPA Effect}

As shown in Table 2, the average GPA of female students was roughly 3.40 and of male students around 3.29. Our goal in this section is to determine whether a student's GPA has an impact on his/her perception of what constitutes good academic advising. For simplicity, we considered students' responses only in the "very important" alternative. We classified the GPA in four categories: 2.0-2.5(a), 2.51-3.00(b), 3.01-3.5(c), and 3,51-4.00(d) and in table 8 we have listed the top ten responses of students in each category. The GPA effect was mixed. Those with the 
lowest GPA chose questions \#7, \#29, and \#3 as their top three choices. For the second GPA group (2.51-3.00) these same questions ranked $2^{\text {nd }}, 7^{\text {th }}$, and $8^{\text {th }}$, respectively. These two groups also listed question \#20 among their top ten $\left(6^{\text {th }}\right.$ for the lowest GPA group and $1^{\text {st }}$ for the $2^{\text {nd }}$ lowest). By contrast, students at the two highest GPA levels (3.01-3,5 and 3.51-4.0) listed question \#9 (addresses me informally by calling me by my first name) among their top choices $\left(6^{\text {th }}\right.$ and $10^{\text {th }}$ respectively); while this question was not even in the top ten of the lowest GPA groups. This issue has been discussed in earlier studies. It was found that the use of the first name by advisors was related to the academic performance and personal fulfillment of students (Pascarella, 1980). Fielstein (1987) found that most students thought their advisors should be personally acquainted with their advisees and as a result should address their students informally. On the other hand, some investigators explained that the increased formality created by the use of a student's formal name would result in a higher perception of professionalism and respect as found in the business environment (Adams, et al, 1990). We found that only students with 2.51-3.0 GPA preferred to be addressed formally by their advisors by using "Mr." or Ms". Students in the lowest GPA group, however, did not perceive this question as their top ten priorities.

Another interesting point was that the top choice for each GPA group was different. The most successful students wanted an advisor who was friendly (question \#3) while those in the lowest group needed an advisor willing to discuss their personal problems (question \#9). These choices are quite consistent with each group's academic performance - the lowest needing an advisor who would understand and sympathize with their academic difficulties and the other, without academic problems, wanting only a friendly advisor. Students in 2.51-3 GPA level felt that advisors should be more concern about their point of view than any other issue (question \#20). The last student group with a GPA of 3.01-3.5 chose question \#28(refers me to appropriate services when needed) as their first priority.

Although Table 8 revealed some interesting and diverse results it was not clear that there was a case for concluding that the GPA impacted students' perceptions of what constituted good advising. Therefore we continued our investigation through the use of the second version of chi-square methodology. The results of this test are illustrated in Table 9. We employed six pair of possible combinations. In all but only two questions, there was a significant difference in the responses of students in group A (GPA 2.0-2.5) and group B (2.51-3.0). Similarly, there existed a significant difference in the response behavior of group A and group C (3.01-3.5) as well as group A and group D (3.51-4.0). The only pair in which there was no significant difference was group B and group D. Thus we concluded the GPA does indeed play a role in students' perception of the advising process, especially with those from the bottom GPA group.

\section{Student's Age Effect}

Our purpose in this section was to determine if age was a factor in a student's evaluation of advising. We divided the students into four age groups: 18-20, 21-23, 24-26, 27 and older (table 8). As before we identified the top ten choices of students in each category and we found a significant difference in several answers. For younger students, age18-20, the most important advisor's characteristic was his/her friendly attitude. Perhaps one possible explanation for this result is that younger students want to begin their advising experience as smoothly as possible in a friendly environment. For the older students in the 24-26 and the 27-29 age groups, the foremost issue was the advisor's willingness to discuss their problems. One possible explanation for this issue could be the fact that they were just about to graduate and hence wanted to figure out all possible problems. Students in the 21-23 age group, on the other hand, selected question \# 13(understands general studies and major requirements) as their first choice. Perhaps at this stage in their student life they were most concerned about choosing a major. We concluded that age was a factor in students' perception of advising but for further assurance we employed the second version of the chisquare testing in which we paired the following age groups: 18-20/21-23, 21-23/24-26, 24-26/27-29, 18-20/24-26, 1820/27-29, and 21-23/27-29. We found a significant difference in the responses of four of the pairings (21-23/24-26, 18-20/24-26, 18-20/27-29, and 21-23/27-29) demonstrating that age does, indeed, influence student responses.

\section{Student's School Effect}

Finally, we examined the impact of the student's school on their perception of the advising process. Table 11 represents the top 10 selections of students in the "very important" category from the three schools. Architecture and 
Design students were primarily concerned with question \#28(refers me to appropriate services when needed), an information related concern. In the School of Arts and Sciences, students desired to establish a more intimate and friendly relationship with their advisor and thus picked question $\# 9$ as their first choice. Business students' main concern, on the other hand, was to work with an experienced advisor (question \#4), an information related skill. For further clarification we examined the chi-square. Data on Table 11 postulates a possibility of school effect, but for further investigation, we, again, resorted to the second version of the chi-square hypothesis testing using three pairings (Architecture/Arts and Science, Architecture/Business, Arts and Science/Business).

Table 12 illustrates the results. Both Business School/Arts \&Science, and Architectures \&Design/Business Schools students' preferences were quite different from each other. Thus confirming that a student's school does make a difference in student responses.

\section{DISCUSSION AND CONCLUSION:}

In this study, 225 students in an urban, private university were asked to complete 29 structured questions in the Fall 2005. Each question asked the student to rank on a scale of one to five the importance of a characteristic and/or responsibility of an academic advisor. In addition, students were asked to provide some cultural, personal, and academic information on themselves including class status, GPA, age, gender, school and ethnicity.

Based on data in this study, we found that students with different personal and cultural attributes (age, gender, ethnicity, school, GPA, and class level) had quite different perceptions of their advisor. This result was demonstrated by employing two types of evaluation techniques. First we utilized the top ten responses of students in each category as measured in percentages. This analysis allowed us to explore a possible relationship between a student's perception of advising and his/her personal and social characteristics. Accordingly, we found that in almost each and every case students had quite different perceptions of what characteristics/responsibilities of an advisor were important and these varying perceptions were based on the students own personal and cultural attributes.

To reconfirm the obtained results, we also employed the chi-square hypothesis testing at a 5\% significance level. Two types of hypotheses test were used: one to explore whether there was a relationship, or, a goodness of fit between questions and parameters and the second hypothesis was used to examine whether the probability of student's response to each selected question, given the five alternatives, was equal. The results of these tests vividly revealed that a student's personal, cultural, and academic background played a major rule in academic advising process. Ignoring and/or mitigating these determinant factors in any effective advising program would damage student retention and, thereby, would have an adverse impact on the university's budgetary goal.

Student's satisfaction in advising cannot be fulfilled unless a faculty advisor is aware of needs and desires of diverse student bodies in today's colleges and universities. Those advisors, who are aware of these social and personal characteristics of their advisees, can incorporate them in their advising process to build a dynamic and structured advising system. We further suggest that these issues should be taken into account when an institution is developing advising assessment instruments.

As was demonstrated in this study, student's perception varied by age group, GPA level, class status level, ethnicity level as well as school. This variation in student's behavior reflects the developmental aspect of advising as was suggested by Crookston (1972). According to the author, the developmental approach focuses on students' potential rather than viewing them as static receivers of input. Students are mature and responsible and interact with their advisor in a developmental process. The student- advisor relationship is built on mutual understanding and sharing. In this process, students learn to achieve educational, personal, and career goals through aids provided by their advisors and the institution. Advisors serve as facilitators exploring student needs and desires based on the student's social, personal, and cultural background (Couch, 2004). In addition, " the interplay among academic, social, personal, and cultural issues is critical to diverse student success...Academic advisors who understand how quality of life issues can influence the college experience are more likely to be successful with diverse students"(Torres, 2003, p.343). 
Table 1: Woodbury University Students Perception Of Effective Academic Advising Fall 2005

\begin{tabular}{|c|c|c|c|c|c|}
\hline \multicolumn{6}{|c|}{ Please rate the following activities based on your perception of effective academic advisor. } \\
\hline & \begin{tabular}{|c|} 
Very \\
Important
\end{tabular} & Important & \begin{tabular}{l|} 
Somewhat \\
Important
\end{tabular} & \begin{tabular}{c|c|} 
Not \\
Important
\end{tabular} & $\begin{array}{l}\text { Don't } \\
\text { Know }\end{array}$ \\
\hline \multicolumn{6}{|l|}{ Keeps personal information confidential } \\
\hline \multicolumn{6}{|l|}{ Is trustworthy } \\
\hline \multicolumn{6}{|l|}{ Is friendly } \\
\hline \multicolumn{6}{|l|}{ Is experienced } \\
\hline \multicolumn{6}{|l|}{ Listens to me } \\
\hline \multicolumn{6}{|l|}{ Has a sense of humor } \\
\hline \multicolumn{6}{|l|}{ Is willing to discuss my personal problems } \\
\hline \multicolumn{6}{|c|}{ Is available during posted office hours } \\
\hline \multicolumn{6}{|c|}{ Addresses me informally by calling me my first name } \\
\hline \multicolumn{6}{|c|}{ Addresses me formally by calling me Mr. or Ms. } \\
\hline \multicolumn{6}{|c|}{\begin{tabular}{|l|l} 
Seems to enjoy advising \\
\end{tabular}} \\
\hline \multicolumn{6}{|c|}{$\begin{array}{l}\text { Discusses course selection \& helps me to select appropriate } \\
\text { courses with my abilities }\end{array}$} \\
\hline \multicolumn{6}{|c|}{\begin{tabular}{|l|l} 
Understands general studies and major requirements & \\
\end{tabular}} \\
\hline \multicolumn{6}{|l|}{ Talks to me out of his/her office } \\
\hline \multicolumn{6}{|l|}{ Arranges his/her schedule to meet with me } \\
\hline \multicolumn{6}{|l|}{ Is concerned about my academic life } \\
\hline \multicolumn{6}{|l|}{ Offers encouragement } \\
\hline \multicolumn{6}{|l|}{ Helps me to decide on a major/minor } \\
\hline \multicolumn{6}{|l|}{ Knows requirements for graduation } \\
\hline \multicolumn{6}{|c|}{ Understands my point of view } \\
\hline \multicolumn{6}{|c|}{ Is knowledgeable about academic policies \& procedures } \\
\hline \multicolumn{6}{|c|}{ Encourages me to take my own decisions } \\
\hline \multicolumn{6}{|l|}{ Discusses my academic progress with me } \\
\hline \multicolumn{6}{|c|}{ Is approachable \& easy to talk with } \\
\hline \multicolumn{6}{|c|}{ Is a helpful, effective advisor whom I would recommend } \\
\hline \multicolumn{6}{|c|}{ Is familiar with my academic background } \\
\hline \multicolumn{6}{|l|}{ Understands my needs } \\
\hline \multicolumn{6}{|l|}{ Refers me to appropriate services when needed } \\
\hline Makes most of my course selection decisions & & & & & \\
\hline
\end{tabular}




\section{Table 2: Demographic Characteristics of Students}

\begin{tabular}{|c|c|c|c|}
\hline Characteristics & Female & Male & Total \\
\hline Gender & 140 & 82 & 222 \\
\hline Freshman (Fr) & 21 & 14 & 35 \\
\hline Sophomore (So) & 28 & 19 & 47 \\
\hline Junior $(\mathrm{Ju})$ & 47 & 28 & 75 \\
\hline Senior & 41 & 18 & 59 \\
\hline Age: $18-20$ & 73 & 28 & 111 \\
\hline $21-23$ & 46 & 30 & 76 \\
\hline $24-26$ & 10 & 15 & 25 \\
\hline $27-29$ & 5 & 7 & 12 \\
\hline GPA: $2-2.5$ & 3 & 7 & 10 \\
\hline $2.51-3$ & 21 & 23 & 44 \\
\hline $3.01-3.5$ & 45 & 19 & 64 \\
\hline $3.51-4$ & 23 & 12 & 35 \\
\hline Ethnicity: Armenian (Ar) & 18 & 14 & 32 \\
\hline \begin{tabular}{|c|} 
Hispanic $(\mathrm{Hi})$ \\
\end{tabular} & 49 & 16 & 65 \\
\hline Asian (As) & 15 & 10 & 25 \\
\hline White (W) & 21 & 12 & 33 \\
\hline African American & 4 & 6 & 10 \\
\hline \begin{tabular}{|c|} 
Others \\
\end{tabular} & 14 & 12 & 26 \\
\hline School: Architecture \& Design & 35 & 27 & 62 \\
\hline Arts \& Science & 36 & 13 & 49 \\
\hline Business & 69 & 40 & 109 \\
\hline
\end{tabular}


Table 3: "Very Important" Category

\begin{tabular}{|c|c|c|c|}
\hline Top Ten Choices *Number in ( ) are in Percentages & & & $\begin{array}{l}\text { Chi-Square Test } \\
\text { Result }\end{array}$ \\
\hline & Female & Male & Female/Male \\
\hline Keeps personal information confidential & $(82.1) 4$ & $5(72.9)$ & Significant \\
\hline Is trustworthy & & & Significant \\
\hline Is friendly & & & Significant \\
\hline Is experienced & $(87.8) 2$ & $1(82.9)$ & Significant \\
\hline Listens to me & $(87.1) 3$ & $3(79.3)$ & Significant \\
\hline Has a sense of humor & & & Significant \\
\hline Is willing to discuss my personal problems & & & Significant \\
\hline Is available during posted office hours & $(65.9) 9$ & $10(58.5)$ & Significant \\
\hline Addresses me informally by calling me my first name & & & Not Significant \\
\hline Addresses me formally by calling me Mr. or Ms. & & & Significant \\
\hline Seems to enjoy advising & & & Significant \\
\hline $\begin{array}{l}\text { Discusses course selection \& helps me to select appropriate courses with my } \\
\text { abilities }\end{array}$ & $(81) 5$ & & Significant \\
\hline \begin{tabular}{|l|l|} 
Understands general studies and major requirements \\
\end{tabular} & & & Significant \\
\hline Talks to me out of his/her office & & & Significant \\
\hline Arranges his/her schedule to meet with me & & & Significant \\
\hline Is concerned about my academic life & $(64.7) 10$ & & Significant \\
\hline Offers encouragement & & & Significant \\
\hline Helps me to decide on a major/minor & & & Significant \\
\hline Knows requirements for graduation & $(92.7) 1$ & $2(80)$ & Significant \\
\hline Understands my point of view & & $8(58.7)$ & Significant \\
\hline Is knowledgeable about academic policies \& procedures & $(78.8) 6$ & & Significant \\
\hline Encourages me to take my own decisions & & $9(58.7)$ & Significant \\
\hline Discusses my academic progress with me & & & Significant \\
\hline Is approachable \& easy to talk with & $(76.6) 7$ & $6(72)$ & Significant \\
\hline Is a helpful, effective advisor whom I would recommend & $(74.5) 8$ & $4(74.7)$ & Significant \\
\hline Is familiar with my academic background & & & Significant \\
\hline Understands my needs & & $7(62.7)$ & Significant \\
\hline Refers me to appropriate services when needed & & & Significant \\
\hline Makes most of my course selection decisions & & & Not Significant \\
\hline
\end{tabular}


Table 4: "Very Important" Category

\begin{tabular}{|c|c|c|c|c|}
\hline Top Ten Choices *Number in ( ) are in Percentages & Freshman & Sophomore & Junior & Senior \\
\hline Keeps personal information confidential & & $(91.8) 2$ & $(73.6) 5$ & $(82) 5$ \\
\hline Is trustworthy & $(80) 6$ & $(95.8) 1$ & $(84.2) 3$ & $(90.2) 2$ \\
\hline Is friendly & $(71.4) 10$ & & & \\
\hline Is experienced & $(85.7) 3$ & $(83.3) 4$ & $(88.2) 4$ & $(86.9) 4$ \\
\hline Listens to me & $(91.4) 1$ & $(81.3) 5$ & $(86.8) 2$ & $(82) 5$ \\
\hline \multicolumn{5}{|l|}{ Has a sense of humor } \\
\hline Is willing to discuss my personal problems & & $(68.1) 10$ & & $(67.2) 10$ \\
\hline \multicolumn{5}{|l|}{ Is available during posted office hours } \\
\hline \multicolumn{5}{|l|}{ Addresses me informally by calling me my first name } \\
\hline \multicolumn{5}{|l|}{ Addresses me formally by calling me Mr. or Ms. } \\
\hline \multicolumn{5}{|l|}{ Seems to enjoy advising } \\
\hline Discusses course selection \& helps me to select appropriate courses with my abilities & $(82.4) 5$ & $(77.8) 7$ & $(75.3) 6$ & $(79.7) 6$ \\
\hline Understands general studies and major requirements & $(85.3) 4$ & $(80) 6$ & $(87.7) 1$ & $(87.9) 3$ \\
\hline \multicolumn{5}{|l|}{ Talks to me out of his/her office } \\
\hline \multicolumn{5}{|l|}{ Arranges his/her schedule to meet with me } \\
\hline \multicolumn{5}{|l|}{ Is concerned about my academic life } \\
\hline Offers encouragement & & & $(61.6) 10$ & \\
\hline \multicolumn{5}{|l|}{ Helps me to decide on a major/minor } \\
\hline Knows requirements for graduation & $(88.2) 2$ & $(88.9) 3$ & $(87.7) 1$ & $(91.5) 1$ \\
\hline \multicolumn{5}{|l|}{ Understands my point of view } \\
\hline Is knowledgeable about academic policies \& procedures & $(73.5) 8$ & $(77.8) 7$ & $(78.1) 8$ & $(72.9) 10$ \\
\hline \multicolumn{5}{|l|}{ Encourages me to take my own decisions } \\
\hline Discusses my academic progress with me & $(70.6) 9$ & $(73.3) 9$ & & \\
\hline Is approachable \& easy to talk with & $(76.5) 7$ & $(75.6) 8$ & $(79.6) 7$ & $(75) 8$ \\
\hline Is a helpful, effective advisor whom I would recommend & & $(80) 6$ & $(76.7) 9$ & $(76.3) 7$ \\
\hline \multicolumn{5}{|l|}{ Is familiar with my academic background } \\
\hline \multicolumn{5}{|l|}{ Understands my needs } \\
\hline \multicolumn{5}{|l|}{ Refers me to appropriate services when needed } \\
\hline Makes most of my course selection decisions & & & & \\
\hline
\end{tabular}


Table 5: "Very Important" Category

\begin{tabular}{|c|c|c|c|c|}
\hline \multicolumn{5}{|l|}{ Chi-Square Test Results } \\
\hline & Fr So & Ju $\quad$ Se & Fr Se & So $\mathbf{J u}$ \\
\hline Keeps personal information confidential & $\mathrm{S}$ & NS & $\mathrm{S}$ & NS \\
\hline Is trustworthy & $\mathrm{S}$ & NS & $\mathrm{S}$ & NS \\
\hline Is friendly & NS & NS & $\mathrm{S}$ & NS \\
\hline Is experienced & $\mathrm{S}$ & NS & $\mathrm{S}$ & NS \\
\hline Listens to me & NS & NS & $\mathrm{S}$ & $\mathrm{S}$ \\
\hline Has a sense of humor & NS & NS & NS & NS \\
\hline Is willing to discuss my personal problems & NS & NS & NS & NS \\
\hline Is available during posted office hours & $\mathrm{S}$ & NS & $\mathrm{S}$ & NS \\
\hline Addresses me informally by calling me my first name & $\mathrm{S}$ & NS & NS & NS \\
\hline Addresses me formally by calling me Mr. or Ms. & NS & NS & NS & NS \\
\hline Seems to enjoy advising & NS & NS & NS & NS \\
\hline Discusses course selection \& helps me to select appropriate courses with my abilities & NS & NS & $\mathrm{S}$ & NS \\
\hline Understands general studies and major requirements & NS & NS & $\mathrm{S}$ & $\mathrm{S}$ \\
\hline Talks to me out of his/her office & $\mathrm{S}$ & NS & NS & NS \\
\hline Arranges his/her schedule to meet with me & $\mathrm{S}$ & NS & NS & NS \\
\hline Is concerned about my academic life & NS & NS & NS & NS \\
\hline Offers encouragement & NS & NS & NS & NS \\
\hline Helps me to decide on a major/minor & NS & NS & $\mathrm{S}$ & NS \\
\hline Knows requirements for graduation & NS & NS & NS & NS \\
\hline Understands my point of view & NS & NS & $\mathrm{S}$ & NS \\
\hline Is knowledgeable about academic policies \& procedures & NS & NS & NS & NS \\
\hline Encourages me to take my own decisions & NS & NS & NS & NS \\
\hline Discusses my academic progress with me & NS & NS & NS & NS \\
\hline Is approachable \& easy to talk with & NS & NS & NS & NS \\
\hline Is a helpful, effective advisor whom I would recommend & NS & NS & $\mathrm{S}$ & NS \\
\hline Is familiar with my academic background & NS & NS & NS & NS \\
\hline Understands my needs & NS & NS & NS & NS \\
\hline Refers me to appropriate services when needed & NS & NS & NS & NS \\
\hline Makes most of my course selection decisions & $\mathrm{S}$ & NS & $\mathrm{S}$ & NS \\
\hline
\end{tabular}

$* \mathrm{Fr}=$ Freshman, So $=$ Sophomore, $\mathrm{Ju}=$ Junior, Se = Senior

$\mathrm{S}=$ Significant, NS $=$ Not Significant 
Table 6: "Very Important" Category

\begin{tabular}{|c|c|c|c|c|c|}
\hline \multicolumn{6}{|l|}{ Top Ten Choices *Number in ( ) are in Percentages } \\
\hline \multicolumn{6}{|l|}{ Ethnicity Groups } \\
\hline & $(\mathbf{A r})$ & (Hi) & (As) & $(\mathbf{W})$ & (Af) \\
\hline Keeps personal information confidential & $(81.8) 4$ & $(84.6) 4$ & $(66.7) 8$ & $(70.6) 8$ & $(81.8) 4$ \\
\hline Is trustworthy & $(97) 1$ & $(84.7) 3$ & $(81.5) 2$ & $(92) 1$ & $(90.9) 2$ \\
\hline \multicolumn{6}{|l|}{ Is friendly } \\
\hline Is experienced & $(97) 1$ & $(89.2) 2$ & $(77.8) 3$ & $(84.85) 5$ & $(70) 7$ \\
\hline Listens to me & $(87.9) 2$ & $(81.5) 6$ & $(74.1) 6$ & $(90.09) 2$ & $(100) 1$ \\
\hline \multicolumn{6}{|l|}{ Has a sense of humor } \\
\hline \multicolumn{6}{|l|}{ Is willing to discuss my personal problems } \\
\hline \multicolumn{6}{|l|}{ Is available during posted office hours } \\
\hline \multicolumn{6}{|l|}{ Addresses me informally by calling me my first name } \\
\hline \multicolumn{6}{|l|}{ Addresses me formally by calling me Mr. or Ms. } \\
\hline \multicolumn{6}{|l|}{ Seems to enjoy advising } \\
\hline $\begin{array}{l}\text { Discusses course selection \& helps me to select appropriate courses with my } \\
\text { abilities }\end{array}$ & $(75) 6$ & $(76.2) 8$ & $\begin{array}{c}(61.5) \\
10\end{array}$ & & $(88.9) 3$ \\
\hline Understands general studies and major requirements & $(87.5) 3$ & $(82.6) 5$ & $(84.6) 1$ & $(91) 2$ & $(100) 1$ \\
\hline \multicolumn{6}{|l|}{ Talks to me out of his/her office } \\
\hline \multicolumn{6}{|l|}{ Arranges his/her schedule to meet with me } \\
\hline \multicolumn{6}{|l|}{ Is concerned about my academic life } \\
\hline \multicolumn{6}{|l|}{ Offers encouragement } \\
\hline \multicolumn{6}{|l|}{ Helps me to decide on a major/minor } \\
\hline Knows requirements for graduation & $(87.5) 3$ & $(90.5) 1$ & $(76.9) 5$ & $(87.8) 4$ & $(100) 1$ \\
\hline \multicolumn{6}{|l|}{ Understands my point of view } \\
\hline Is knowledgeable about academic policies \& procedures & $(71.9) 8$ & $(77.8) 7$ & $(65.4) 9$ & $(78.8) 7$ & $(77.8) 5$ \\
\hline \multicolumn{6}{|l|}{ Encourages me to take my own decisions } \\
\hline \multicolumn{6}{|l|}{ Discusses my academic progress with me } \\
\hline Is approachable \& easy to talk with & $(75) 7$ & $(77.8) 7$ & $(73.1) 7$ & $(78.9) 6$ & $(77.8) 5$ \\
\hline Is a helpful, effective advisor whom I would recommend & $(78.1) 5$ & $(77.8) 7$ & (76.9) 4 & $(78.8) 9$ & $(55.6) 8$ \\
\hline Is familiar with my academic background & $(62.5) 9$ & $(73) 9$ & & $(54.54) 10$ & $(66.7) 6$ \\
\hline \multicolumn{6}{|l|}{ Understands my needs } \\
\hline Refers me to appropriate services when needed & $(56.3) 10$ & $(66.7) 10$ & & $(66.7) 9$ & $(66.7) 6$ \\
\hline Makes most of my course selection decisions & & & & & \\
\hline
\end{tabular}


Table 7: Very Important Category

\begin{tabular}{|c|c|c|c|c|c|c|c|c|c|}
\hline & Ar/Hi & Hi/As & $\mathbf{A s} / \mathbf{W}$ & W/Af & Af/Ar & Af/Hi & Af/As & $\mathrm{Hi} / \mathbf{W}$ & $\mathbf{A r} / \mathbf{W}$ \\
\hline Keeps personal info. confidential & $\mathrm{S}$ & $\mathrm{S}$ & NS & NS & $\mathrm{S}$ & $\mathrm{S}$ & $\mathrm{NS}$ & $\mathrm{S}$ & NS \\
\hline Is trustworthy & $\mathrm{S}$ & $\mathrm{S}$ & NS & $\mathrm{S}$ & $\mathrm{S}$ & $\mathrm{S}$ & NS & $\mathrm{S}$ & NS \\
\hline Is friendly & $\mathrm{S}$ & $\mathrm{S}$ & NS & $\mathrm{S}$ & $\mathrm{S}$ & $\mathrm{S}$ & NS & $\mathrm{S}$ & NS \\
\hline Is experienced & $\mathrm{S}$ & $\mathrm{S}$ & NS & $\mathrm{S}$ & $\mathrm{S}$ & $\mathrm{S}$ & $\mathrm{S}$ & $\mathrm{S}$ & NS \\
\hline Listens to me & $\mathrm{S}$ & $\mathrm{S}$ & $\mathrm{NS}$ & $\mathrm{S}$ & $\mathrm{S}$ & $\mathrm{S}$ & $\mathrm{S}$ & $\mathrm{S}$ & $\mathrm{NS}$ \\
\hline Has a sense of humor & NS & NS & NS & NS & NS & NS & NS & NS & NS \\
\hline Is willing to discuss my personal problems & NS & NS & NS & NS & NS & NS & NS & NS & NS \\
\hline Is available during posted office hours & $\mathrm{S}$ & $\mathrm{S}$ & NS & NS & $\mathrm{S}$ & $\mathrm{S}$ & NS & $\mathrm{S}$ & NS \\
\hline $\begin{array}{l}\text { Addresses me informally by calling me my } \\
\text { first name }\end{array}$ & NA** & NA & NA & NA & NA & NA & NA & NA & NA \\
\hline $\begin{array}{l}\text { Addresses me formally by calling me Mr. } \\
\text { Ms. }\end{array}$ & NA & NA & NA & NA & NA & NA & NA & NA & NA \\
\hline Seems to enjoy advising & NS & $\mathrm{S}$ & NS & $\mathrm{S}$ & $\mathrm{S}$ & $\mathrm{S}$ & $\mathrm{S}$ & $\mathrm{S}$ & NS \\
\hline $\begin{array}{l}\text { Discusses course selection \& helps me to } \\
\text { select appropriate courses with my abilities }\end{array}$ & $\mathrm{S}$ & $\mathrm{S}$ & NS & $\mathrm{S}$ & $\mathrm{S}$ & $\mathrm{S}$ & $\mathrm{S}$ & $\mathrm{S}$ & NS \\
\hline $\begin{array}{l}\text { Understands general studies and major } \\
\text { requirements }\end{array}$ & $\mathrm{S}$ & $\mathrm{S}$ & NS & $\mathrm{S}$ & $\mathrm{S}$ & $\mathrm{S}$ & $\mathrm{S}$ & $\mathrm{S}$ & NS \\
\hline Talks to me out of his/her office & NA & NA & $\mathrm{NA}$ & NA & NA & NA & NA & NA & NA \\
\hline Arranges his/her schedule to meet with me & NA & NA & NA & NA & NA & NA & NA & NA & NA \\
\hline Is concerned about my academic life & $\mathrm{S}$ & $\mathrm{S}$ & NS & NS & NS & $\mathrm{S}$ & NS & $\mathrm{S}$ & NS \\
\hline Offers encouragement & $\mathrm{S}$ & $\mathrm{S}$ & NS & $\mathrm{S}$ & NS & $\mathrm{S}$ & SS & $\mathrm{S}$ & NS \\
\hline Helps me to decide on a major/minor & $\mathrm{S}$ & $\mathrm{S}$ & NS & NS & NS & $\mathrm{S}$ & $\mathrm{NS}$ & $\mathrm{S}$ & NS \\
\hline Knows requirements for graduation & $\mathrm{S}$ & $\mathrm{S}$ & NS & NS & NS & $\mathrm{S}$ & NS & $\mathrm{S}$ & NS \\
\hline Understands my point of view & $\mathrm{S}$ & $\mathrm{S}$ & NS & $\mathrm{S}$ & $\mathrm{S}$ & $\mathrm{S}$ & NS & $\mathrm{S}$ & NS \\
\hline $\begin{array}{l}\text { Is knowledgeable about academic policies \& } \\
\text { procedures }\end{array}$ & $\mathrm{S}$ & $\mathrm{S}$ & NS & $\mathrm{S}$ & $\mathrm{S}$ & $\mathrm{S}$ & $\mathrm{S}$ & $\mathrm{S}$ & NS \\
\hline Encourages me to take my own decisions & $\mathrm{S}$ & $\mathrm{S}$ & $\mathrm{S}$ & $\mathrm{S}$ & $\mathrm{S}$ & $\mathrm{S}$ & NS & $\mathrm{S}$ & NS \\
\hline Discusses my academic progress with me & NS & $\mathrm{S}$ & $\mathrm{NS}$ & $\mathrm{S}$ & $\mathrm{S}$ & $\mathrm{S}$ & $\mathrm{NS}$ & $\mathrm{S}$ & NS \\
\hline Is approachable \& easy to talk with & $\mathrm{S}$ & $\mathrm{S}$ & NS & $\mathrm{S}$ & $\mathrm{S}$ & $\mathrm{S}$ & NS & $\mathrm{S}$ & NS \\
\hline $\begin{array}{l}\text { Is a helpful, effective advisor whom I would } \\
\text { recommend }\end{array}$ & NA & NA & NA & NA & NA & NA & NA & NA & NA \\
\hline Is familiar with my academic background & $\mathrm{S}$ & $\mathrm{S}$ & NS & $\mathrm{S}$ & $\mathrm{S}$ & $\mathrm{S}$ & NS & $\mathrm{S}$ & NS \\
\hline Understands my needs & $\mathrm{S}$ & $\mathrm{S}$ & NS & $\mathrm{S}$ & $\mathrm{S}$ & $\mathrm{S}$ & NS & $\mathrm{S}$ & NS \\
\hline $\begin{array}{l}\text { Refers me to appropriate services when } \\
\text { needed }\end{array}$ & $\mathrm{S}$ & $\mathrm{S}$ & NS & $\mathrm{S}$ & $\mathrm{S}$ & $\mathrm{S}$ & NS & $\mathrm{S}$ & NS \\
\hline $\begin{array}{l}\text { Makes most of my course selection } \\
\text { decisions }\end{array}$ & NS & NS & NS & NS & NS & NS & NS & NS & $\mathrm{NS}$ \\
\hline & & & & & & & & & \\
\hline
\end{tabular}

$\mathrm{Ar}=$ Armenian, $\mathrm{W}=$ White, $\mathrm{Hi}=$ Hispanic, $\mathrm{Af}=$ African American, As = Asian

$\mathrm{S}=$ Significant, NS $=$ Not Significant, NA** $=$ Not Available due to violation of Chi Square Assumptions, NA = Not Available *Obtained Chi-Square statistics $\left(=\sum \frac{(f o-f e) 2}{f e}\right)$ was greater than critical Chi-Square @ 5\% significance level for a given d.o.f. 
Table 8: "Very Important" Category

\begin{tabular}{|c|c|c|c|c|c|c|c|c|}
\hline \multicolumn{9}{|l|}{ Top Ten Choices *Number in ( ) are in Percentages } \\
\hline & \multicolumn{3}{|c|}{ GPA } & & \multicolumn{3}{|c|}{ Age } & \multirow[b]{2}{*}{$27-29$} \\
\hline & $2-2.50$ & $2.51-3$ & $3.03-3.5$ & $3.52-4$ & $18-20$ & $21-23$ & $24-26$ & \\
\hline Keeps personal information confidential & $9(5.6)$ & & & & & & $3(10.4)$ & \\
\hline Is trustworthy & $5(6.2)$ & & & $5(24.8)$ & & & $2(11.5)$ & $7(4.6)$ \\
\hline Is friendly & $10(5.51)$ & $8(29.1)$ & & $1(31.6)$ & $4(51)$ & & & \\
\hline Is experienced & $7(5.9)$ & & & $7(24.7)$ & $9(48.2)$ & & $5(9.6)$ & \\
\hline Listens to me & $5(6.3)$ & & $10(45.3)$ & $9(24.5)$ & & & & $5(5.9)$ \\
\hline Has a sense of humor & & & & & & & & $2(6.6)$ \\
\hline Is willing to discuss my personal problems & $1(9.7)$ & $2(31.7)$ & & & & $9(40.1)$ & $1(11.6)$ & $1(8.3)$ \\
\hline Is available during posted office hours & & $5(31)$ & & & & $10(40)$ & & $4(6)$ \\
\hline Addresses me informally by calling me my first name & & & $6(46.5)$ & $10(24.3)$ & & $6(41.6)$ & & $3(6.5)$ \\
\hline Addresses me formally by calling me Mr. or Ms. & & $7(30)$ & & $2(30)$ & & & & \\
\hline Seems to enjoy advising & & $8(29.1)$ & $4(49.7)$ & & $5(50.9)$ & & & \\
\hline $\begin{array}{l}\text { Discusses course selection \& helps me to select appropriate } \\
\text { courses with my abilities }\end{array}$ & $5(6.3)$ & & $9(45.6)$ & & & $8(40.7)$ & & $6(5.4)$ \\
\hline Understands general studies and major requirements & $8(5.6)$ & & & $6(24.8)$ & & $1(45.2)$ & $10(8.4)$ & \\
\hline Talks to me out of his/her office & & & $8(45.9)$ & & & $2(45.5)$ & & \\
\hline Arranges his/her schedule to meet with me & & $4(33.1)$ & $2(50.9)$ & & $1(61.2)$ & & & \\
\hline Is concerned about my academic life & & & $3(50.1)$ & & & $3(42.8)$ & & \\
\hline Offers encouragement & & $6(30.5)$ & $5(47.9)$ & & & & & \\
\hline Helps me to decide on a major/minor & $3(6.9)$ & $7(30)$ & & & $2(54.1)$ & & $7(9.2)$ & $8(4.5)$ \\
\hline Knows requirements for graduation & $8(5.3)$ & & & $4(25.5)$ & & & $5(9.6)$ & $7(4.6)$ \\
\hline Understands my point of view & $6(6)$ & 1 (34.9) & & $8(24.6)$ & $7(49.2)$ & & & \\
\hline Is knowledgeable about academic policies \& procedures & & $10(28.7)$ & & $5(25.4)$ & $8(48.3)$ & & $9(8.8)$ & $9(4.4)$ \\
\hline Encourages me to take my own decisions & $4(6.5)$ & $9(28.8)$ & & & $3(53.1)$ & & & \\
\hline Discusses my academic progress with me & & $7(30)$ & $7(46)$ & & $6(49.9)$ & & & \\
\hline Is approachable \& easy to talk with & & & & & & & $6(9.5)$ & \\
\hline Is a helpful, effective advisor whom I would recommend & $5(6.3)$ & & & & & & $4(10.2)$ & $10(4.3)$ \\
\hline Is familiar with my academic background & & & & $3(28.5)$ & & $7(41.4)$ & & \\
\hline Understands my needs & & & & & & $7(41.4)$ & & \\
\hline Refers me to appropriate services when needed & $4(6.5)$ & $3(30.6)$ & $1(52.4)$ & & & & $8(8.6)$ & \\
\hline Makes most of my course selection decisions & $2(8.9)$ & $7(30)$ & & & & $5(41.9)$ & $6(9.5)$ & \\
\hline
\end{tabular}


Table 9: "Very Important" Category

\begin{tabular}{|c|c|c|c|c|c|c|}
\hline \multicolumn{7}{|l|}{$\begin{array}{rr}\text { Chi-Square Test Results } \\
\end{array}$} \\
\hline \multicolumn{7}{|l|}{ ** Not available due to violation of Chi Square assumptions } \\
\hline & \multicolumn{6}{|c|}{ GPA } \\
\hline & A vs B & B vs C & C vs D & A vs C & A vs D & B vs D \\
\hline Keeps personal information confidential & $\mathrm{S}$ & $\mathrm{S}$ & $\mathrm{S}$ & $\mathrm{S}$ & $\mathrm{S}$ & NS \\
\hline Is trustworthy & $\mathrm{S}$ & $\mathrm{S}$ & $\mathrm{S}$ & $\mathrm{S}$ & $\mathrm{S}$ & NS \\
\hline Is friendly & $\mathrm{S}$ & $\mathrm{S}$ & $\mathrm{S}$ & $\mathrm{S}$ & $\mathrm{S}$ & NS \\
\hline Is experienced & $\mathrm{S}$ & NS & NS & $\mathrm{S}$ & $\mathrm{S}$ & NS \\
\hline Listens to me & $\mathrm{S}$ & $\mathrm{S}$ & $\mathrm{S}$ & $\mathrm{S}$ & $\mathrm{S}$ & NS \\
\hline Has a sense of humor & NS & $\mathrm{S}$ & NS & $\mathrm{S}$ & Not & NS \\
\hline Is willing to discuss my personal problems & NS & $\mathrm{S}$ & NS & $\mathrm{S}$ & Not & NS \\
\hline Is available during posted office hours & $\mathrm{S}$ & $\mathrm{S}$ & $\mathrm{S}$ & $\mathrm{S}$ & $\mathrm{S}$ & NS \\
\hline Addresses me informally by calling me my first name & NS & NS & NS & NS & NS & NS \\
\hline Addresses me formally by calling me Mr. or Ms. & NS & NS & NS & NS & NS & NS \\
\hline Seems to enjoy advising & $\mathrm{S}$ & $\mathrm{S}$ & $\mathrm{S}$ & $\mathrm{S}$ & $\mathrm{S}$ & NS \\
\hline $\begin{array}{l}\text { Discusses course selection \& helps me to select appropriate courses with my } \\
\text { abilities }\end{array}$ & $\mathrm{S}$ & $\mathrm{S}$ & $\mathrm{S}$ & $\mathrm{S}$ & $\mathrm{S}$ & NS \\
\hline Understands general studies and major requirements & $\mathrm{S}$ & NS & $\mathrm{S}$ & $\mathrm{S}$ & $\mathrm{S}$ & NS \\
\hline Talks to me out of his/her office & $\mathrm{S}$ & NS & Not & $\mathrm{S}$ & NS & NS \\
\hline Arranges his/her schedule to meet with me & $\mathrm{N} / \mathrm{A} * *$ & N/A & N/A & N/A & N/A & N/A \\
\hline Is concerned about my academic life & $\mathrm{S}$ & $\mathrm{S}$ & $\mathrm{S}$ & $\mathrm{S}$ & $\mathrm{S}$ & NS \\
\hline Offers encouragement & $\mathrm{S}$ & NS & $\mathrm{S}$ & $\mathrm{S}$ & $\mathrm{S}$ & NS \\
\hline Helps me to decide on a major/minor & $\mathrm{S}$ & NS & NS & $\mathrm{S}$ & Not & NS \\
\hline Knows requirements for graduation & $\mathrm{S}$ & NS & NS & $\mathrm{S}$ & $\mathrm{S}$ & NS \\
\hline Understands my point of view & $\mathrm{S}$ & NS & NS & $\mathrm{S}$ & $\mathrm{S}$ & NS \\
\hline Is knowledgeable about academic policies \& procedures & $\mathrm{S}$ & NS & NS & $\mathrm{S}$ & $\mathrm{S}$ & NS \\
\hline Encourages me to take my own decisions & $\mathrm{S}$ & NS & NS & $\mathrm{S}$ & $\mathrm{S}$ & NS \\
\hline Discusses my academic progress with me & $\mathrm{S}$ & NS & NS & $\mathrm{S}$ & $\mathrm{S}$ & NS \\
\hline Is approachable \& easy to talk with & $\mathrm{S}$ & NS & NS & $\mathrm{S}$ & $\mathrm{S}$ & NS \\
\hline Is a helpful, effective advisor whom I would recommend & $\mathrm{S}$ & NS & $\mathrm{S}$ & $\mathrm{S}$ & $\mathrm{S}$ & NS \\
\hline Is familiar with my academic background & $\mathrm{S}$ & $\mathrm{S}$ & $\mathrm{S}$ & $\mathrm{S}$ & $\mathrm{S}$ & NS \\
\hline Understands my needs & $\mathrm{S}$ & NS & NS & $\mathrm{S}$ & $\mathrm{S}$ & NS \\
\hline Refers me to appropriate services when needed & $\mathrm{S}$ & NS & $\mathrm{S}$ & $\mathrm{S}$ & $\mathrm{S}$ & NS \\
\hline Makes most of my course selection decisions & $\mathrm{S}$ & NS & $\mathrm{S}$ & $\mathrm{S}$ & $\mathrm{S}$ & NS \\
\hline
\end{tabular}

$* \mathrm{~A}=2-2.50 \quad \mathrm{~B}=2.51-3$

$\mathrm{C}=3.01-3.5 \quad \mathrm{D}=3.51-4$ 


\section{Table 10: "Very Important" Category}

\begin{tabular}{|c|c|c|c|c|c|c|}
\hline \multicolumn{7}{|l|}{ Chi-Square Test Results } \\
\hline & \multicolumn{6}{|c|}{ Age } \\
\hline & $\mathrm{a} \quad \mathrm{b}$ & $\mathrm{b} \quad \mathrm{c}$ & $\mathrm{c} \mathrm{d}$ & $\mathrm{a} \quad \mathrm{c}$ & $\mathrm{a} d \mathrm{~d}$ & $\mathrm{~b} \quad \mathrm{~d}$ \\
\hline Keeps personal information confidential & NS & $\mathrm{S}$ & $\mathrm{S}$ & $\mathrm{S}$ & $\mathrm{S}$ & $\mathrm{S}$ \\
\hline Is trustworthy & NS & $\mathrm{S}$ & $\mathrm{S}$ & $\mathrm{S}$ & $\mathrm{S}$ & $\mathrm{S}$ \\
\hline Is friendly & NS & $\mathrm{S}$ & NS & $\mathrm{S}$ & $\mathrm{S}$ & $\mathrm{S}$ \\
\hline Is experienced & NS & $\mathrm{S}$ & NS & $\mathrm{S}$ & $\mathrm{S}$ & $\mathrm{S}$ \\
\hline Listens to me & NS & $\mathrm{S}$ & NS & $\mathrm{S}$ & $\mathrm{S}$ & $\mathrm{S}$ \\
\hline Has a sense of humor & NS & $\mathrm{S}$ & NS & NS & NS & $\mathrm{S}$ \\
\hline Is willing to discuss my personal problems & NS & $\mathrm{S}$ & NS & $\mathrm{S}$ & $\mathrm{S}$ & $\mathrm{S}$ \\
\hline Is available during posted office hours & NS & $\mathrm{S}$ & NS & $\mathrm{S}$ & $\mathrm{S}$ & $\mathrm{S}$ \\
\hline Addresses me informally by calling me my first name & NS & $\mathrm{S}$ & NS & $\mathrm{S}$ & $\mathrm{S}$ & $\mathrm{S}$ \\
\hline Addresses me formally by calling me Mr. or Ms. & NS & --- & --- & --- & --- & --- \\
\hline Seems to enjoy advising & $\mathrm{S}$ & $\mathrm{S}$ & NS & $\mathrm{S}$ & $\mathrm{S}$ & $\mathrm{S}$ \\
\hline Discusses course selection \& helps me to select appropriate courses with my abilities & NS & $\mathrm{S}$ & NS & $\mathrm{S}$ & $\mathrm{S}$ & $\mathrm{S}$ \\
\hline Understands general studies and major requirements & NS & $\mathrm{S}$ & NS & $\mathrm{S}$ & $\mathrm{S}$ & $\mathrm{S}$ \\
\hline Talks to me out of his/her office & NS & NS & $\mathrm{S}$ & $\mathrm{S}$ & $\mathrm{S}$ & $\mathrm{S}$ \\
\hline Arranges his/her schedule to meet with me & $\mathrm{S}$ & $\mathrm{S}$ & NS & $\mathrm{S}$ & $\mathrm{S}$ & $\mathrm{S}$ \\
\hline Is concerned about my academic life & NS & $\mathrm{S}$ & NS & $\mathrm{S}$ & $\mathrm{S}$ & $\mathrm{S}$ \\
\hline Offers encouragement & NS & $\mathrm{S}$ & NS & $\mathrm{S}$ & $\mathrm{S}$ & $\mathrm{S}$ \\
\hline Helps me to decide on a major/minor & $\mathrm{S}$ & $\mathrm{S}$ & NS & $\mathrm{S}$ & $\mathrm{S}$ & $\mathrm{S}$ \\
\hline Knows requirements for graduation & NS & NS & $\mathrm{S}$ & $\mathrm{S}$ & $\mathrm{S}$ & $\mathrm{S}$ \\
\hline Understands my point of view & NS & $\mathrm{S}$ & NS & $\mathrm{S}$ & $\mathrm{S}$ & $\mathrm{S}$ \\
\hline Is knowledgeable about academic policies \& procedures & NS & $\mathrm{S}$ & NS & $\mathrm{S}$ & $\mathrm{S}$ & $\mathrm{S}$ \\
\hline Encourages me to take my own decisions & NS & $\mathrm{S}$ & NS & $\mathrm{S}$ & $\mathrm{S}$ & $\mathrm{S}$ \\
\hline Discusses my academic progress with me & NS & $\mathrm{S}$ & NS & $\mathrm{S}$ & $\mathrm{S}$ & $\mathrm{S}$ \\
\hline Is approachable \& easy to talk with & NS & $\mathrm{S}$ & NS & $\mathrm{S}$ & $\mathrm{S}$ & $\mathrm{S}$ \\
\hline Is a helpful, effective advisor whom I would recommend & NS & $\mathrm{S}$ & NS & $\mathrm{S}$ & $\mathrm{S}$ & $\mathrm{S}$ \\
\hline Is familiar with my academic background & NS & $\mathrm{S}$ & $\mathrm{S}$ & $\mathrm{S}$ & \begin{tabular}{|c|}
----- \\
-19
\end{tabular} & $--\cdot-\cdot$ \\
\hline Understands my needs & NS & $\mathrm{S}$ & NS & $\mathrm{S}$ & $\mathrm{S}$ & $\mathrm{S}$ \\
\hline Refers me to appropriate services when needed & NS & $\mathrm{S}$ & NS & $\mathrm{S}$ & $\mathrm{S}$ & $\mathrm{S}$ \\
\hline Makes most of my course selection decisions & NS & $\mathrm{S}$ & NS & $\mathrm{S}$ & $\mathrm{S}$ & $\mathrm{S}$ \\
\hline $\begin{array}{ll}* a=18-20 & b=21-23 \\
c=24-26 & d=27-29\end{array}$ & & & & & & \\
\hline
\end{tabular}




\section{Table 11: "Very Important" Category}

\begin{tabular}{|c|c|c|c|}
\hline \multirow[t]{2}{*}{ Top Ten Choices *Number in ( ) are in Percentages } & \multicolumn{3}{|c|}{ Schools } \\
\hline & Architecture & $\begin{array}{c}\text { Arts \& } \\
\text { Science }\end{array}$ & Business \\
\hline Keeps personal information confidential & & & $(62.3) 4$ \\
\hline Is trustworthy & $(18.8) 6$ & & \\
\hline Is friendly & $(18.2) 8$ & & \\
\hline Is experienced & $(17.6) 9$ & & $(89.5) 1$ \\
\hline Listens to me & $(19.5) 4$ & & \\
\hline Has a sense of humor & & $(33.3) 3$ & \\
\hline Is willing to discuss my personal problems & & $(29.6) 4$ & \\
\hline Is available during posted office hours & $(18.5) 7$ & & $(60) 9$ \\
\hline Addresses me informally by calling me my first name & & $(40.7) 1$ & \\
\hline \multicolumn{4}{|l|}{ Addresses me formally by calling me Mr. or Ms. } \\
\hline Seems to enjoy advising & & $(26.9) 7$ & \\
\hline Discusses course selection \& helps me to select appropriate courses with my abilities & & & $(61.6) 6$ \\
\hline Understands general studies and major requirements & & & $(60) 9$ \\
\hline Talks to me out of his/her office & & $(37.9) 2$ & \\
\hline Arranges his/her schedule to meet with me & & & $(66.7) 3$ \\
\hline Is concerned about my academic life & & $(26.6) 8$ & $(59.4) 10$ \\
\hline Offers encouragement & (20) 3 & & $(61.7) 6$ \\
\hline Helps me to decide on a major/minor & $(18) 8$ & & \\
\hline Knows requirements for graduation & & & $(61.6) 7$ \\
\hline Understands my point of view & (17) 10 & $(26.4) 10$ & \\
\hline Is knowledgeable about academic policies \& procedures & & & $(61.8) 5$ \\
\hline Encourages me to take my own decisions & $(18.8) 6$ & & $(60.4) 8$ \\
\hline Discusses my academic progress with me & $(17.6) 9$ & $(26.5) 9$ & \\
\hline Is approachable \& easy to talk with & $(20.3) 2$ & & \\
\hline \multicolumn{4}{|l|}{ Is a helpful, effective advisor whom I would recommend } \\
\hline \multicolumn{4}{|l|}{ Is familiar with my academic background } \\
\hline Understands my needs & $(19.6) 5$ & $(27.5) 6$ & \\
\hline Refers me to appropriate services when needed & $(21.2) 1$ & & $(68.5) 2$ \\
\hline Makes most of my course selection decisions & & (27.6) 5 & \\
\hline
\end{tabular}


Table 12: "Very Important" Category

\begin{tabular}{|c|c|c|c|}
\hline \multirow[t]{2}{*}{ Chi-Square Test Results @ 5\% } & \multicolumn{3}{|c|}{ Schools } \\
\hline & \begin{tabular}{|c|} 
Architecture \\
/ Arts \& \\
Science \\
\end{tabular} & $\begin{array}{c}\text { Architecture } \\
\text { / Business }\end{array}$ & $\begin{array}{c}\text { Arts \& } \\
\text { Science / } \\
\text { Business } \\
\end{array}$ \\
\hline Keeps personal information confidential & NS & $\mathrm{S}$ & $\mathrm{S}$ \\
\hline Is trustworthy & NS & $\mathrm{S}$ & $\mathrm{S}$ \\
\hline Is friendly & NS & $\mathrm{S}$ & $\mathrm{S}$ \\
\hline Is experienced & NS & $\mathrm{S}$ & $\mathrm{S}$ \\
\hline Listens to me & NS & $\mathrm{S}$ & $\mathrm{S}$ \\
\hline Has a sense of humor & NS & $\mathrm{S}$ & $\mathrm{S}$ \\
\hline Is willing to discuss my personal problems & NS & $\mathrm{S}$ & $\mathrm{S}$ \\
\hline Is available during posted office hours & NS & $\mathrm{S}$ & $\mathrm{S}$ \\
\hline Addresses me informally by calling me my first name & NS & $\mathrm{S}$ & NS \\
\hline Addresses me formally by calling me Mr. or Ms. & NS & NS & NS \\
\hline Seems to enjoy advising & NS & $\mathrm{S}$ & $\mathrm{S}$ \\
\hline Discusses course selection \& helps me to select appropriate courses with my abilities & NS & S & $\mathrm{S}$ \\
\hline Understands general studies and major requirements & NS & S & $\mathrm{S}$ \\
\hline Talks to me out of his/her office & NS & $\mathrm{S}$ & NS \\
\hline Arranges his/her schedule to meet with me & NS & $\mathrm{S}$ & $\mathrm{S}$ \\
\hline Is concerned about my academic life & $\mathrm{S}$ & $\mathrm{S}$ & $\mathrm{S}$ \\
\hline Offers encouragement & NS & $\mathrm{S}$ & $\mathrm{S}$ \\
\hline Helps me to decide on a major/minor & NS & $\mathrm{S}$ & $\mathrm{S}$ \\
\hline Knows requirements for graduation & NS & $\mathrm{S}$ & $\mathrm{S}$ \\
\hline Understands my point of view & NS & $\mathrm{S}$ & $\mathrm{S}$ \\
\hline Is knowledgeable about academic policies $\&$ procedures & NS & $\mathrm{S}$ & $\mathrm{S}$ \\
\hline Encourages me to take my own decisions & NS & $\mathrm{S}$ & $\mathrm{S}$ \\
\hline Discusses my academic progress with me & NS & $\mathrm{S}$ & $\mathrm{S}$ \\
\hline Is approachable \& easy to talk with & NS & $\mathrm{S}$ & $\mathrm{S}$ \\
\hline Is a helpful, effective advisor whom I would recommend & NS & $\mathrm{S}$ & $\mathrm{S}$ \\
\hline Is familiar with my academic background & NS & $\mathrm{S}$ & $\mathrm{S}$ \\
\hline Understands my needs & NS & $\mathrm{S}$ & $\mathrm{S}$ \\
\hline Refers me to appropriate services when needed & NS & $\mathrm{S}$ & $\mathrm{S}$ \\
\hline Makes most of my course selection decisions & NS & $\mathrm{S}$ & $\mathrm{S}$ \\
\hline
\end{tabular}

\section{REFERENCES}

1. Adams, Rebecca J., Greene, Kathryn L., Hocking, John E., Smith, Mary Ann and Lichner, Kimberly (Fall 1990). Effects of Forms of Address on Advisee's Perceptions of Advisors, NACADA Journal Volume 10 (2), pp. 14-18.

2. Afshar, Tahmoures and O'Hara, Leo (2005). Student Perception of Academic Advising in Proceeding of the Fifth Annual Hawaii International Conference on Business, Honolulu, Hawaii, May 26-29.

3. Astin, A.W. (1993), What Matters in College? Four Critical Years Revisited. San Francisco: Jossey-Bass Publishers.

4. Backhus, D. (1989). Centralized Intrusive Advising and Undergraduate Retention. NACADA Journal 9, pp. 39-45.

5. Burnett, D. and Oblinger, D. (2003). Student Academic Services, Current Practices and Trends. In Kranner, G.L. \& Associates (Eds), Students Academic Services. An Integrated Approach (pp. 27-52). San Francisco: Jossey-Bass Publishers.

6. Crockett, D.S. (1978). Academic Advising : A cornerstone of student retention. In Noel, L.(Ed.), New directions for student services: Reducing the dropout rate(pp.29-38). San Francisco: Jossey-Bass Publishers. 
7. Couch, Renee Chaffin (2004). Trends in Sophomore Students' Perceptions of Academic Advising Services at East Tennessee State University. Doctor of Education Dissertation.

8. Creamer, D.S. (2000). Use of Theory in Academic Advising. In Gordon, V.N., Habley, W.R. and Associates, Academic Advising: A Comprehensive Handbook (pp. 18-34). San Francisco: Jossey Bass Publisher.

9. Crookston, R.B. (1972). A Developmental View of Academic Advising as Testing. Journal of College Student Personnel, 13 (1), pp. 12-17.

10. Fielstein, Linda (1989). Student Priorities for Academic Advising, Do They Want a Personal Relationship. NACADA Journal 9 (1), pp. 33-38.

11. Fielstein, Linda (1987). Student Preferences for Personal Contact in a Student/Faculty Advising Relationship. NACADA Journal, 7 (2), pp. 34-40.

12. Gravetter, Frederick J. and Wallnau, Larry B. (2004). Statistics for the Behavioral Sciences, $6^{\text {th }}$ ed. Thompson/Southwestern.

13. Kelly, Karl N. and Lynch, Mary Jean (Spring 1991). Factors Students Use When Evaluating Advisors. NACADA Journal, 7 (2), pp. 34-40.

14. King, M.C. (1993). Academic Advising: Organizing \& Delivering Services for Student Success. New Direction for Community Colleges, No. 82. San Francisco: Jossey-Bass Publishers.

15. Levitz, R.S., Noel, L., and Richter, B.J. (1999). Strategic Moves from Retention Success. In Gaither, G (Ed.), Promising Practices in Recruitment, Retention \& Remediation, New Direction for Higher Education, 108 (pp. 31-49). San Francisco: Jossey-Bass Publishers.

16. Light, R.L. (2001). Making the Most of College. Students Speak Their Minds. Cambridge, MA: Harvard University Press.

17. Lowe, Anna and Toney, Michael (2000). Academic Advising: Views of Givers \& Takers, Baywood Publishing Co., Inc., pp. 83-106.

18. Pascarella, E. (1980). Student-Faculty Informal Contact and College Outcome. Review of Educational Research, 50, pp. 545-595.

19. Torres, V. (2003). Student Diversity \& Academic Services. Balancing the Needs of All Students. In Kramer, G.L. \& Associates (Eds), Student Academic Services. An Integrated Approach, pp. 333-351. San Francisco: Jossey-Bass Publishers. 